\title{
Articles
}

\section{Opportunities for Dialogue in Counselling with the Special Education Students}

\section{Petra Jurkovičová}

\begin{abstract}
In the article presented, we sum up the information and research conclusions collected, confronting them with theoretical knowledge in the field of dialogue approach, using dialogue to create the space for understanding, help and change. We open the discussion for using the dialogue approach in teaching the special education students in order to increase their competences for working with clients.
\end{abstract}

Key words: dialogue, counselling, special needs education.

\section{Prostor pro dialog v poradenské (spolu)práci se studenty speciální pedagogiky}

\section{Abstrakt}

V tomto článku prezentujeme shromážděné informace a výzkumné závěry, které konfrontujeme s teoretickými znalostmi v oblasti dialogického př́stupu. Pomocí dialogu vytváríme prostor pro pochopení, pomoc a změnu. Otevíráme diskusi o využívání dialogického př́stupu při výuce studentů speciální pedagogiky s cílem zvýšit jejich kompetence pro práci s klienty.

Klíčová slova: dialog, poradenství, speciální pedagogika. 


\section{Introduction}

As Bakhtin stated in his famous quote: "For the word (and consequently for the human being) there is nothing more terrible than a lack of response." (Bakhtin, 1984)

In the situations of personal crisis, when a person cannot solve their issues in their own usual way and the problems restrict or absorb them, the dialogue in its complexity may be the only rescue. We will focus on describing the space needed for the dialogue, created by the dialogue itself and the method whereby it is transforming the space. We understand the term space as the synonym for time, place, content, communication method, reflecting the personality, subjective historical and ethical experiences of both communicating persons. Their ideas, expectations, the feelings of threat or pressure, influence of relatives ones, internal and external dialogues, communication skills and habits. And still, the dialogue is not only the speech, information exchange. We understand it as a complex of all communication forms, including the cultural and local habits reflected in the perception, production and understanding of such communication.

\section{Dialogue in Counselling - Research Methodology}

In the counselling work, dialogue is one of the most important methods. It enables to create and accept the primary contact of both persons and subsequent mutual creation of meanings of all that has been said. It is the mutual meeting and connection that enables to understand and cope with the difficulty of the situation.

In such case, keeping a dialogue and using its complexity depends on the abilities and skills of both participants. In the text below, we will take a closer look at this method of counselling through comparing the theory and results of the educational experiment.

\subsection{Goals}

The primary goal of the research was to define the process of acquiring skills for involving dialogue in counselling for the special education students. When analysing the theoretical basis for the dialogue and collaborative approach and during the research itself, we were dealing with many questions refining and steering our research.

a) How to adapt the educational space and content to enable the students to experience the dialogue approach?

b) What dialogue-related skills can be applied in reading and which have to be transmitted through personal experience?

c) What attributes define the space for dialogue and enable acquisition of the skill to work in a dialogue way? 
Over two years, in the teaching focusing on counselling in special education, we have adapted the work content and methods and applied the dialogue and collaborative approach.

We have divided the conclusions of the analysis by using the grounded theory method into three conflict areas reported by students in their statements, actions and activities.

\subsection{Understanding versus Expertise}

The university environment itself and the educational process puts pressure on the students to become experts in the issues, clients, diagnoses. This results in an intense pressure on the beginner counsellors to be experts in their field. However, this is often meant as expertise in the client's situation and the ability to assess the problem within the shortest possible time and to offer an efficient solution. The variety of issues and specific expressions of such issues in clients in special education counselling increase both the information and emotional difficulty of the counselling work. How should the expertise be really viewed by the counsellor and what conflicts do the beginner counsellors come across in the contact with client?

Within the research, the students received the task not to focus on their ideas of the issue, to refrain from the need to "give advice" for as long as possible. Instead, they were supposed to listen to the client's talking and try to understand them the best way possible. This was difficult for most of the students. In spite the assurance that the process will be assessed rather than the result, the students got very tense. The reason was a frequent feeling that if they fail to evaluate the situation quickly and give an advice, they will not be assessed as good counsellors, i.e. they will fail their task. In theory, the counsellor should be an expert regarding the knowledge about clients, the issues and crisis situations they can possibly solve. On the other hand, they should have the skills to professionally use the tools for evaluation and intervention (Dryden, 2008, Jurkovičová, Regec, 2013).

However, in consideration of the cooperating approach and creating the space for dialogue, this knowledge and skills are only the basis, the lead that should help to understand the client's individual situation, experienced and assessed very subjectively.

For the dialogue approach, it is more typical to emphasise the understanding of the client's view than the expert assessment of the situation with respect to an acknowledged expert theory.

Anderson (2009) describes this relationship of expertise and understanding in two basic assumptions postulated for the collaborative practice. In the first one, he mentions the need to remain sceptical in situations when the dominant discourses, expert knowledge, theories and research data may appear as indisputable and definite. When meeting the client, Anderson invites counsellors to be prepared to get to know the 
other person in their subjective complexity. The strong need of a good result lead the students as the beginner counsellors to excessive generalisation of the client's issues, suppressing the importance of individual specifics. In the reactions, we could often hear the consequences of prejudice, traditional understandings and repeated universal truths. The rate of complex perception was decreasing and the area of topics, the client was gradually steered, was narrowing down. Anderson $(1997,2009)$ states that if we think about the client's issue based on a generalised, dominant knowledge, we think more frequently in categories, types or classes that as a result continue to suppress our ability and need to learn and explore the uniqueness of each person. Consequently, we perceive clients and the events in their lives as something known, experienced, identified, instead of unique, worth exploring. Such cognition leads us to procedures based on theoretic knowledge without being confronted with the actual situation. This results in depersonalisation of people and inefficiency of both the mutual meetings and proposed solutions.

On the contrary, in the situations where the students were able to provide freedom and did not identify the importance of any of the topics brought up by clients, the situations were perceived as relaxed and positive (regardless of the severity of the topic). The clients were experiencing the feeling of acceptance and understanding, the feeling of interest in both themselves and in the problem. The tension caused by the situation, pressure for performance as well as the chosen session topic was releasing faster and more efficiently.

From the teacher's point of view, it was also demanding to provide an open space and remain patient. It was difficult to let the students to learn their own openness through the experienced openness. Therefore, the requirement to replace the expertise by understanding was equally important both for the teacher and students. Thereby, the space for release of tension from the performance and assessment originated. For the client in counselling practice, this provides the same benefit, i.e. peaceful environment providing trust and safety regardless of the severity of the issue and options for solution thereof.

\subsection{Empathy versus Professional Distance}

The most frequent response of students about how a counsellor should be is "emphatic". In spite of the fact that empathy is most frequently connected with personality traits, in counselling, we see it as the process consisting of many attributes. Šiffelová (2010) describes empathic understanding as the experience of "deep understanding helping to remove the feeling of loneliness, encouraging to risk the expression of thoughts and feelings" (p. 62). According to Merry (2004), empathy is the result of deep tuning in to the client's inner relationship frame and openness to own feelings springing from the current presence with the particular person. In his words, empathy is the trait originat- 
ing in a relationship. Šiffelová (2010) further writes that the empathic process is unique and unsystematic, not given by a logic sequence of steps. It originates an intimate "familiarisation" (p.63) in the client's subjective world. The counsellor's reactions are not only the responses or reactions following after the client's monologue. They spring from the deep connection and sense of mutual meeting and influencing. The empathic reactions are rather intuitive, since they not only react to what has been said but also include a complex evaluation of the client's existence. (Merry, 2004) Rogers himself considers the empathic understanding as follows: "I don't try to reflect on the feelings. I try to find out whether my understanding of the client's world is correct - if I see it the way they experience the particular moment. Each one of my answers contains an unspoken question. 'Is this how you feel it?"'

If we considered empathy from the dialogue point of view, it is a holistic exchange of attention, understanding and feedback. Bakhtin (1986, p. 68) writes: "Any understanding of live speech, a live utterance, is inherently responsive... Any understanding is imbued with response and necessarily elicits it in one form or another: the listener becomes the speaker..." And the speaker himself is oriented precisely toward such an actively responsive understanding. He does not expect passive understanding that, so to speak, only duplicates his or her own idea in someone else's mind... Rather, the speaker talks with an expectation of a response, agreement, sympathy, objection, execution, and so forth... (p.69) Therefore, in the theoretical framework of counselling, the topics such as active listening, the ability to ask questions and show interest, reflect, make sure the understanding is correct and providing feedback were crucial.The goal was to provide the students with an experience that the level of empathy increases through the feeling of understanding. From the practical point of view, the students were supposed to improve their skills for phrasing statements in compliance with the client's natural vocabulary, for the creation of new mutual meanings of the situations, each of them perceives differently. The task was aimed at supporting the ability to accept different positions, opinions and their meanings flexibly and humbly for each participant.

Together with the students, we often experienced stiffness and a certain "technicality" in their efforts for empathic reactions. In their efforts to apply empathic understanding, the students tended to create the process of two mutually interconnected monologues using the "techniques" instead of a dialogue reflecting the emerging relationship. The reason was frequently the distance felt either towards the particular client or a certain topic. The topics the students usually perceived as problematic were the ones they have come across in a certain way in person. In their reflections, they expressed the worry to be too personal, to bring more of their own personal experiences into the understanding of the problem than the client's.

The students who got rid of this worry and fear and at the same time were able to adhere to the "show your interest" requirement, created the empathic understanding 
much more successfully. They also felt less chaos and more clarity and insight into the client's situation. On the clients' part, they also received confirmation of their empathic understanding and shift in decoding their own situation referred to in the follow-up dialogue.

Another determinant resulting from the mastery of the empathic reaction, was a more open expression of the counsellor's emotions with regard to the current experience and getting closer to the client. This phenomenon is also described by Seikkula (in Seikkula, Trimble, 2005) when defining the healing attributes of a dialogue. The authors talk about a powerful mutual emotional attunement and from the client's position, they call this experience the feelings of love. Within our research, we might talk about a supporting cooperation and conversation between the counsellor and client. In spite of the brief one-off consultation, a more personal relationship was gradually emerging, that could result in a greater responsibility both of the counsellor and client for the issue resolution.

The students' needs were described during joint reflections of the students and teachers. The tension felt and the technicity of the students' reactions was changing significantly if they had the opportunity to experience empathic understanding and see the actual specific examples of the "healing" factors (Seikkula, Trimble, 2005) in the teacher's work. The ability to show interest and reflect on the perceived in connection with the congruent expression of the counsellor made a liberating impression. The fear of assessment was reduced and the need to ask "the right questions" was replaced by honest interest and the need of common exploration.

\section{What is more important, the result or the process? - personal expectations}

Counselling is usually used as the synonym for giving advice, help, support rather than a complex process. Of course, in the personal crisis situations, experiencing difficulties in life, the clients expect quick understanding and efficient solution. They are lead by the need to mitigate the suffering, fear or chaos brought up by their situation. The tension emerging intensifies the most in the cases when the result is uncertain in a long term or repeatedly and the client has no option to create a real image of the future.

Many helping professionals, including counsellors and special pedagogues or social workers are directly confronted with the feelings of suffering and deadlock situations. The tension occurring when meeting the clients intensifies proportionally to the complexity of the particular problem and the options of solution the expert is able to offer and the client is able to accept.

The ability to cope with other person's suffering requires a lot of personality traits we could sum up under the phrase "strong personality". However, in counselling, even 
a strong personality is constantly confronted by the request of help by an expert and the need of help from the client. As a matter of course, the tangible manifestations of help, such as a particular advice, applicable technique, financial aid, etc., are the best result of counselling. However, for the offered solutions to be efficient, certain time and space is needed. The actual solution has to reflect any determinants both on the client's and counsellor's part, or on the part of the counselling institution, where the help should be provided. In some cases, the determining factors are very clear, specific and quickly detectable. At the same time, there are only a few of them.

In a majority of cases, it is necessary to know the wider context of the client's life and the reasons as well as consequences of the issue, in order to adequately suggest help. In the decision making, a great role is played by the client's and counsellor's personal expectations, which do not have to be implicitly expressed.

One of the examples may be the meeting with the client, Ingrid, described by Seikkula. (in Seikkula, Trimble, 2005) In the process of team meeting with the client suffering from a certain psychiatric diagnosis, there were many shifts mainly in the field of releasing emotions, healing of relationships, etc. Individual participants of the meeting, who were in some kind of relationship with the client, reflected positively on the development as well as result of the meeting. The only negative feedback was provided by the social worker. "She was dissatisfied that such strong emotions had been aroused with no concrete decisions being made for how to go on" (p. 464).

However, the authors assessed the result of this as well as other examined cases as successful based on the development of understanding, empathy, openness and in particular the existence of dialogue contributed to by all the participants.

When analysing our meetings with students, the direction towards a particular result was perceived very strongly. Subconsciously, the unspoken expectations of clients lead the counsellors to structure the process more expressly. Communication was showing the signs of a monologue rather than a dialogue. The shorter the time the counsellor was able to keep the space of open exploration, the more frequently the pauses appeared. Working with silence was used by the counsellor predominantly to think through the following question and had no potential of supporting the internal dialogue and exploration.

However, some counselling conversations were more efficient in the creation of dialogical space. In the reverse analysis of the process, we found out that the individual expectations of the counsellor and the client were the determinants significantly influencing the process.

If the counsellor felt a strong interest in the topic and it was attractive for them, they were more attentive and their reactions were exploring, extending the space for different views of the particular issue.

Another example was represented by the meetings where the counsellor was currently solving a similar issue and had yet to make up their own idea how to solve it. In 
such case, the discussion between the counsellor and the client reminded of a dialogue of two colleagues contemplating what strategy to choose and what wiles or help could they expect. In such case, the counsellor's expectation was also based on personal benefit. Joint consideration of the problem has brought them a lot of important information needed for decision making.

Based on our research, we could mark the clients' expectations as less stable, adaptable if the counsellor's reactions and approach to the client as a person were filled with interest and respect.

In his basic assumptions for collaborative practice, Anderson (2009) introduces the "Knowledge as an interactive process" as the third assumption. He explains that even if the knowledge is anchored in the particular systems and theoretical frameworks, it is produced within and through the discussion in the society. Knowledge has an interactive nature and needs an interpretative process, in which all the participants influence the creation, maintenance and modification of knowledge. Therefore, knowledge as well as an advice or procedure, cannot be simply installed into the thinking process of someone else. Through the dialogue confrontation of every person with the content of knowledge, a space emerges for the understanding accepted as personal ownership.

\section{Conclusion}

Interest is the essence of the dialogue approach in counselling. This comprises the interest in the client and their issue, interest in getting to know and understand them, interest in the position and importance of the person of counsellor in the modification process.

The described conflicts were taking place in the moments when the students or teachers were not sure if they may fully express their interest in the given situation and how to do it correctly not to harm the client.

Clarification of these conflicts in every particular situation incites the internal dialogue and is also carried out through the dialogue with client. Interconnection of these two entities enables a complex, dialogue and cooperating (collaborating) process in counselling.

Practically, we could postulate the following recommendations for the university education practice:

- Space and time available for education has to be sufficiently flexible and wide. Theoretical knowledge may be passed on in a classical form of teaching, e.g. in form of a lecture, however, the effect of the information acquired is several times more intense if the theory "only" complements the practical skills practising.

- The practice itself has to be as natural as possible. In this regard, willingness of the students and the teacher to think and talk openly about personal experiences 
and topics is necessary. In this case, role-playing does not enable the increase of the empathy skills because there is always a part of information which is only a made up theory without the leading emotions.

- The skills to be passed on to students must be presented by the teacher in an extent and quality to be clear, repeatable and open to discussion. This does not comprise a practice of possible techniques but a way of personal input, personal decision on the action and approach to others. The teacher has to be congruent in their actions in practical demonstrations.

- Final assessment of the students' work within the subject has to be strictly separated from the "counselling results", i.e. from the success rate of individual students in practising the skills since the very beginning. Within the introductory discussion, the requirements for the subject evaluation as well as the expectations towards the students' work during the teaching process shall be clarified. Subsequently, this ethical viewpoint of the education organisation may serve as the lead for transferring the skills and knowledge from teaching to the counselling practice.

\section{References}

Anderson, H. (1997). Conversation, Language and Possibilities. A postmodern approach to therapy. NY: Basic Books.

Anderson, H. (2009). Collaborative practice: Relationships and conversations that make a difference. In Bray, J. H., \& Stanton, M. (2011). The handbook of family psychology. Malden, Mass: Wiley-Blackwell.

Bakhtin, M., M. (1984). Problems of Dostoevsky's Poetics. Minneapolis, MN: University of Minnesota Press.

Bakhtin, M., M., McGee, V. W., Emerson, C., \& Holquist, M. (1986). Speech Genres and Other Late Essays. Austin: University of Texas.

Dryden, W. (2008). Poradenství. Praha: Portál.

Jurkovičová, P. \& Regec, V. (2013). Úvod do speciálněpedagogického poradenství. Olomouc: PdF UP. Merry, T. (2004). Naučte sa byt' poradcom - poradenstvo zamerané na človeka. Bratislava: Ikar.

Seikkula, J., \& Trimble, D. (December 01, 2005). Healing Elements of Therapeutic Conversation: Dialogue as an Embodiment of Love. Family Process, 44, 4, 461-475.

Šiffelová, D. (2010). Rogersovská psychoterapie pro 21. století: Vybraná témata z historie a současnosti. Praha: Grada.

\section{Contact:}

Mgr. Petra Jurkovičová, Ph.D.

Institute of Special Education Studies

Faculty of Education, Palacký University in Olomouc

Žižkovo nám. 5, 77140 Olomouc, Czech Republic

E-mail: petra.jurkovicova@upol.cz 
Mgr. Petra Jurkovičová, Ph.D. studied Special needs Education at the Faculty of Education of the Comenius University in Bratislava. 2008 received a Ph.D. in the Special needs Education at the Palacký University in Olomouc, with a focus on counseling and family work. During doctoral studies she began to teach at the Department of Special Education, now the Institute of Special Education Studies. In 2011, she completed comprehensive training in Person centered Psychotherapy in the Institute Ister in Bratislava, and in 2013 training in Dialogical and Postmodern Approach to counseling and psychotherapy organized by Narativ group in Brno. Theoretically and practically focuses on counseling, therapeutic and supervision activities, particularly in the field of working with families caring a child or adult with disabilities. Currently, she also works as a counselor of the Special Education Center for People with Intellectual Disabilities and Autism.

\section{Successfully Defended Dissertation at the Faculty of Education,}

\section{Palacký University in Olomouc}

\section{Cross-cultural perspectives on pedagogical leadership in schools providing compulsory education}

\section{Danping Peng}

The main aims of this study are exploring the concepts of pedagogical leadership, its dimensions from different perspectives, and the factors influencing it in educational practice. The researcher adopted a qualitative paradigm, and collected data through semi-structured interview and written interview. Grounded theory approach was applied to analyze the qualitative data, and to develop theories that can further interpret the reality and offer new insights into the development of pedagogical leadership.

Based on the data collected, the researcher summarized the current situation of pedagogical leadership in selected Czech schools, and outlined the characteristics of pedagogical leadership from different perspectives. The dimensions of pedagogical leadership, the characteristics of the good actors in pedagogical leadership and the challenges faced by the development of pedagogical leadership were elaborated.

Having illustrated the current situation of pedagogical leadership in selected schools. Barriers and facilitators which were found in the two coding paradigms of PL have been summarized. The barriers included: (1) financial limitation of school, (2) conflicts between various roles, (3) low social recognition of teacher's profession, (4) massive administrative work, (4) teacher retention and recruitment. The facilitators comprised: (1) appreciation of the teaching profession, (2) supportive management team, (3) supports from family, (4) supportive pedagogical leader. In the final part, recommendations have been proposed, including: (1) to offer trainings for different stages of school leaders, (2) to improve the diversity of implementation of pedagogical leadership. 